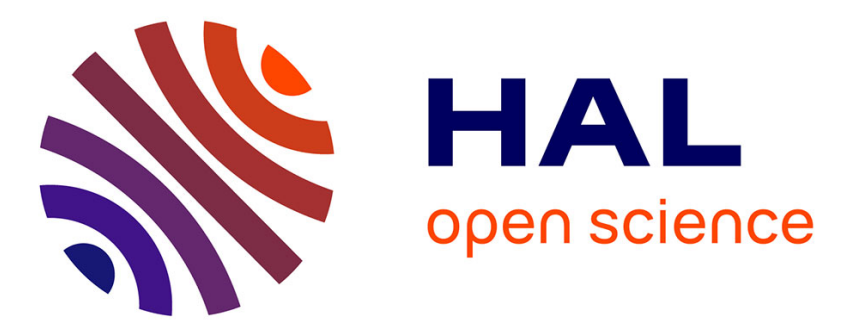

\title{
An investigation of the physical, thermal and mechanical properties of fired clay/SiC ceramics for thermal energy storage
}

Abdoul Razac Sane, Pierre-Marie Nigay, Doan Pham Minh, Claudia Toussaint, Alain Germeau, Nawal Semlal, Rachid Boulif, Ange Nzihou

\section{To cite this version:}

Abdoul Razac Sane, Pierre-Marie Nigay, Doan Pham Minh, Claudia Toussaint, Alain Germeau, et al.. An investigation of the physical, thermal and mechanical properties of fired clay/SiC ceramics for thermal energy storage. Journal of Thermal Analysis and Calorimetry, 2020, 140, pp.2087 - 2096. 10.1007/s10973-019-08964-5 . hal-02385780

\section{HAL Id: hal-02385780 \\ https://imt-mines-albi.hal.science/hal-02385780}

Submitted on 1 Dec 2019

HAL is a multi-disciplinary open access archive for the deposit and dissemination of scientific research documents, whether they are published or not. The documents may come from teaching and research institutions in France or abroad, or from public or private research centers.
L'archive ouverte pluridisciplinaire HAL, est destinée au dépôt et à la diffusion de documents scientifiques de niveau recherche, publiés ou non, émanant des établissements d'enseignement et de recherche français ou étrangers, des laboratoires publics ou privés. 


\title{
An investigation of the physical, thermal and mechanical properties of fired clay/SiC ceramics for thermal energy storage
}

\author{
Abdoul Razac Sane ${ }^{1} \cdot$ Pierre-Marie Nigay ${ }^{1} \cdot$ Doan Pham Minh $^{1,2}\left(\right.$ Claudia Toussaint $^{3} \cdot$ Alain Germeau $^{3}$. \\ Nawal Semlal ${ }^{4} \cdot$ Rachid Boulif $^{5} \cdot$ Ange Nzihou $^{1}$
}

\begin{abstract}
Thermal energy storage (TES) has been identified as a breakthrough concept in development of renewable technologies. However, the main challenges are related to the development of competitive heat storage materials. Despite the number of studies on heat storage materials, the determination of new alternatives for next generation technologies is still open. In this regard, this paper presents the results of an experimental study of the physical, thermal and mechanical properties of SiC-doped ceramics as potential materials for TES applications. Two kinds of $\mathrm{SiC}$ additives (high and low densities) were incorporated with different percentages into the clay matrix in order to produce ceramics via the extrusion process. The addition of low-density $\mathrm{SiC}$ (true density $3.16 \mathrm{~g} \mathrm{~cm}^{-3}$ ) led to the increasing of porosity with large pore sizes and the decreasing of bulk density. Therefore, the thermal and mechanical properties are decreased up to $-50 \%$ for flexural strength and $-15 \%$ for thermal conductivity when 20 mass $\%$ of low-density SiC was used. On the other hand, when high-density $\mathrm{SiC}$ (true density $3.42 \mathrm{~g} \mathrm{~cm}^{-3}$ ) was used, properties of the clay ceramic were strongly improved: i.e., increase in the bulk density, decrease in the porosity, increase in the thermal conductivity and increase in the flexural strength. The best material was found with the addition of 20 mass $\%$ of high-density $\mathrm{SiC}$ which had a thermal conductivity of $1 \mathrm{~W} \mathrm{~m}^{-1} \mathrm{~K}^{-1}$, a specific heat capacity of $0.62 \mathrm{~kJ} \mathrm{~kg}^{-1} \mathrm{~K}^{-1}$ and a mechanical strength of $19.6 \mathrm{MPa}$. It also showed a high thermal stability after 20 successive heating/cooling cycles. Hence, this study provided a useful insight into how the $\mathrm{SiC}$ modified the microstructure and properties of fired clay ceramics. Thus, the current results suggest that clay ceramics with high-density SiC addition are promising materials for thermal energy storage applications.
\end{abstract}

Keywords SiC Clay $\cdot$ Ceramic $\cdot$ Thermal energy storage $\cdot$ Thermal analysis $\cdot$ Thermal properties $\cdot$ Mechanical strength . Microstructure

Doan Pham Minh

doan.phamminh@mines-albi.fr

1 Université de Toulouse, IMT Mines Albi, CNRS, Centre RAPSODEE, Campus Jarlard, 81013 Albi Cedex 09, France

2 Institute of Research and Development, Duy Tan University, Da Nang 550000, Vietnam

3 PRAYON SA, Service R\&D, Rue Joseph Wauters 144, 4480 Engis, Belgium

4 Innovation, OCP SA, BP 118, 24000 El Jadida, Morocco

5 Chemical and Biochemical Sciences, Mohamed VI Polytechnic University, Benguérir, Morocco

\section{Introduction}

Thermal energy storage (TES) can be considered as a significant technology in responding to the intermittency of renewable energy sources, in particular for solar energy [1]. Typically, the extra production of energy is stored in the form of heat/cold and restored at the next period of unavailability. There are different concepts for TES systems, but in all cases, a storage media is needed [1-3].

Currently, sensible heat storage is the most developed TES concept at the industrial scale, in comparison with the latent heat storage and thermochemical energy storage. It is mainly used in concentrated solar power (CSP) plants. Several implantations are already operating such as ANDASOL [4-7], GEMASOLAR [8, 9], Solana Generating Station [10] and NOOR I [11]. In such CSP plants, the TES media consist 
of molten salt (commercially known as solar salt, a mixture of $\mathrm{KNO}_{3}$ and $\mathrm{NaNO}_{3}$ ) being used in its liquid form (at temperatures above the melting point) [12]. For example, the CSP plant ANDASOL 3 (Spain), which has a forecast gross electricity generation of approximately $200 \mathrm{GWh}$ per year, uses 28,500 tons of molten salt as TES media [6]. The use of molten salt in CSP plants is now well developed. However, molten salt has several disadvantages. When used in CSP plants, molten salt of high quality is required which leads to a high cost of TES media [13, 14]. The type and content of impurities that can be found in molten salt, such as chloride and sulfate, need to be controlled to limit corrosion effect. Some properties of molten salt also need to be improved, in particular its thermal conductivity, heat capacity and thermal stability [13]. Furthermore, nitrate salts are used for other important applications, i.e., fertilizer. The massive use of molten salt in CSP plants can therefore affect its current utilization in agricultural activities. In fact, it is predicted that CSP plants would lead to nitrate salt consumptions 30 times higher than the current worldwide mine production, by 2050 [15]. In addition, the operating range of temperatures remains limited at temperatures between 225 and $600{ }^{\circ} \mathrm{C}[16,17]$ in the case of solar salt. Therefore, molten salt cannot be used in high concentrating systems using heliostats and central receivers at the top of solar towers, where high temperatures are usually reached $\left(800-1000^{\circ} \mathrm{C}\right)$ [18]. Hence, despite the number of advantages of using molten salts, the development of alternative materials for TES is indispensable.

To become a TES medium, alternative materials have to comply with many criteria. These include availability at the industrial scale, low cost, acceptable eco-balance, high thermal stability, good thermophysical properties, high mechanical stability, easy processing and high compatibility with the heat transfer fluids (HTF) [19]. For economic and environmental reasons, the valorization of waste and by-products in TES materials has been widely studied, as previously reviewed by Gutierrez et al. [20]. For example, Faik et al. [15] investigated the valorization of asbestos-containing wastes (ACW) and fly ash (FA). The valorization of slag from electric arc furnace steelmaking processes was also investigated by Ortega-Fernandez et al. [21]. Recently, Motte et al. [22] also investigated the compatibility of such alternative materials (ACW, FA, electric arc furnace slags, converter slags and blast furnace slags) with solar salt as the heat transfer fluid. They found that the most challenging aspect in developing alternative media for TES was the production of materials that are easy to process and handle. High temperature processes, such as plasma processing, have been investigated for the production of those materials. However, it came to an issue due to the high energetic and economical cost. Concrete is easy to process and easy to handle. It is available worldwide and has interesting properties for heat energy storage. Some results obtained from a pilot scale by Laing et al. [23] suggested that concrete storage technology may be a suitable option for storing sensible heat. However, it was shown that the compressive strength of concrete decreased from 29 to about $15 \mathrm{~N} / \mathrm{mm}^{2}$ after several thermal cycles at a temperature of $500{ }^{\circ} \mathrm{C}$ [24]. This means that the use of concrete as TES material remains limited to low temperature storage technologies (i.e., typically below $\left.400{ }^{\circ} \mathrm{C}\right)$.

In contrast, ceramic materials could be used in high concentrating systems due to their thermal stability up to $1000{ }^{\circ} \mathrm{C}$ [19-25]. They would also be suitable for TES due to their easy shaping and handling in the form of bricks, their low cost, their high thermal and mechanical stability as well as their good chemical inertness. Nevertheless, many ceramic materials still have low thermal conductivity and low specific heat capacity [19-26]. Hence, the objective of this study is to investigate the physical, thermal and mechanical properties of silicon carbide-containing fired clay ceramics (SiC/clay) as alternative materials for TES. The choice of fired clay ceramics relates to several advantages, including: the worldwide availability of clay as starting materials; the low cost of clay; the easy handling and shaping of clay-based materials; the low environmental impact of clay since it is a natural starting material; the popularity of clay-based products; the high thermal and mechanical stability of clay-based ceramics; as well as their good chemical inertness. Conventional fired clay products (bricks, roof tiles...) are used as construction material in civil engineering in all countries [27, 28]. Extrusion process allows producing ceramics of controlled shape and size. They have generally high mechanical stability and low thermal expansion coefficient which are favorable for heat energy storage. However, conventional fired clay materials have usually low thermal conductivity because they are elaborated for building application [26]. In order to increase the thermal conductivity of fired clay materials, the incorporation $\mathrm{SiC}$ as additives appears as the most promising option. $\mathrm{SiC}$ is chosen as additive because of its interesting properties for heat energy storage: high thermal and chemical stability, excellent thermal shock resistance, wide range of thermal conductivity with possibility of high value, high erosion and corrosion resistance, very high hardness and strength [29-34]. Thus, the effect of low-density and high-density $\mathrm{SiC}$ additives on the properties of the clay ceramic will be reported. The implications of the results will also be discussed for the use of clay ceramics as alternative materials in TES systems.

\section{Materials and experimental methods}

\section{Raw materials}

The clay that was used in this study was extracted from a clay quarry in Southwest France. The clay was ground into 
particles of $3 \mathrm{~mm}$ using a rolling mill. The silicon carbides $(\mathrm{SiC})$ that were used as additives in the fired clay ceramics were commercial products obtained from SICAT and SAINT-GOBAIN Companies (France). They were named $S i C_{-} L D$ and $S i C_{-} H D$, respectively. The main characteristics of the starting materials are summarized in the results section.

\section{Processing of the clay ceramics}

The clay ceramics that were investigated in this study were made of clay, $\mathrm{SiC}$ additives and water. The mixtures were prepared in a kneading bowl by the mixing of clay with 5 , 10,15 or 20 mass\% of $\mathrm{SiC}$ additives. They were subjected to kneading for 5 min with a gradual addition of water up to 25 mass\%. The mixtures were then extruded using a bench extruder (Reber) composed of a pipe and a crank activated piston. They were pushed in the pipe and released across a die as clay blocks of $60 \times 30 \times 10 \mathrm{~mm}^{3}$. The clay blocks were dried at 25,65 and $105^{\circ} \mathrm{C}$ for $24 \mathrm{~h}$ at each temperature in an electrical oven (Memmert). Samples with desired three dimensions for various characterizations were then prepared from the dried blocks using P80, P120, P180 and P280 abrasive papers (CarbiMet, Buehler). Finally, fired clay ceramics were obtained by heat treatment of the samples in an electrical furnace (Controller P320, Nabertherm). They were fired under air atmosphere at a temperature of $950{ }^{\circ} \mathrm{C}$ using a $5{ }^{\circ} \mathrm{C}$ $\min ^{-1}$ heating rate and kept at this temperature for $1 \mathrm{~h}$. This firing temperature is required for clay densification. Then, sample was freely cooled down to room temperature.

\section{Analyses and characterizations}

Different analyses and characterizations were performed with the raw materials and final fired clay ceramics. Typically, the elemental composition of the clay was determined using X-ray fluorescence analysis (Epsilon 3-XL, PANalytical). The particle size distribution was measured via laser granulometry analysis (Mastersizer 3000, Malvern). Thermogravimetry coupled with differential scanning calorimetry (TG-DSC) was carried out with a Q600 apparatus (TA Instruments) in the temperature range of $30-1100{ }^{\circ} \mathrm{C}\left(5^{\circ} \mathrm{C} /\right.$ $\mathrm{min}$ ) under the air atmosphere. The percentage of $\mathrm{SiC}$ additives was determined by subtracting the mass loss of the clay ceramic. This was done since the thermal behavior of the $\mathrm{SiC}$ additives within the clay matrix is different from that out of the clay matrix.

The specific surface area was determined by gas sorption analysis (nitrogen) using a MICROMETRICS TriStar II 3020 instrument. They were calculated from the desorption isotherm via BET method. The true density was obtained by helium pycnometry analysis (ACCUPYC 1330, Micrometrics). On the other hand, the bulk density was measured using a water absorption technique. The measurements were taken with samples of $30 \times 30 \times 5 \mathrm{~mm}^{3}$. Typically, the samples were introduced in a vacuum chamber and maintained under a residual pressure of $30 \mathrm{kPa}$ for $4 \mathrm{~h}$. Some water was then introduced in the vacuum chamber up to partial immersion of the samples. The samples remained partially immerged under the same residual pressure of $30 \mathrm{kPa}$ for $2 \mathrm{~h}$. Subsequently, the samples were subjected to full immersion in the water. The full immersion of the samples was maintained for $24 \mathrm{~h}$. The atmospheric pressure was finally restored in the vacuum chamber. The samples remained immerged at atmospheric pressure for 24 more hours.

Following this operation, the mass of the samples was measured under three different conditions. It was measured under water by hydrostatic weighing, under air after wet wiping and under air after drying at a temperature of $105{ }^{\circ} \mathrm{C}$ for $24 \mathrm{~h}$. In this way, the bulk density of the samples $\left(\rho_{\text {Bulk }}\right)$ could be calculated from Eq. 1, where $W_{\mathrm{h}}$ is the hydrostatic mass, $W_{\mathrm{w}}$ is the wet mass, and $W_{\mathrm{d}}$ is the dry mass.

$\rho_{\text {Bulk }}=\frac{W_{\mathrm{d}}}{W_{\mathrm{w}}-W_{\mathrm{h}}}$

$\varepsilon=\frac{W_{\mathrm{w}}-W_{\mathrm{d}}}{W_{\mathrm{w}}-W_{\mathrm{h}}} \times 100 \%$.

The percentage of porosity $(\varepsilon)$ was also determined from the results of the three different measurements. In fact, it was obtained from Eq. 2 using the hydrostatic mass $\left(W_{\mathrm{h}}\right)$, the wet mass $\left(W_{\mathrm{w}}\right)$ and the dry mass $\left(W_{\mathrm{d}}\right)$ of the samples.

The microstructure of the $\mathrm{SiC} /$ clay ceramic was observed by scanning electron microscopy (SEM) using a Philips XL 30 instrument. The samples were embedded in a solidifying epoxy resin and polished before the observations in back scattered imaging (BSI) conditions.

The thermal properties of the SiC/clay ceramic were determined using a transitory plane source method (TPS 2500, Hot Disk $\mathrm{AB}$ ). The analyses were performed at room temperature with duplicate samples of $30 \times 30 \times 5 \mathrm{~mm}^{3}$. The thermal conductivity and the volumetric heat capacity were determined after the tests using algorithms of the Thermal Constant Analyzer software. Finally, the specific heat capacity of the samples was calculated from the volumetric heat capacity and the bulk density.

The mechanical properties of the $\mathrm{SiC} /$ clay ceramic were measured in an Instron 5800R machine. The measurements were taken using a three-point bend testing fixture (load span of $40 \mathrm{~mm}$ and a $500 \mathrm{~N}$ load cell). The specimens with dimensions of $60 \times 10 \times 5 \mathrm{~mm}^{3}$ were subjected to a constant displacement rate of $1 \mathrm{~mm} \mathrm{~min}^{-1}$ until the fracture.

$\sigma_{\mathrm{f}}=\frac{3 F_{\mathrm{Max}} L}{2 B H^{2}}$. 
Fig. 1 Procedure for SiC/clay ceramic firing and thermal stability testing

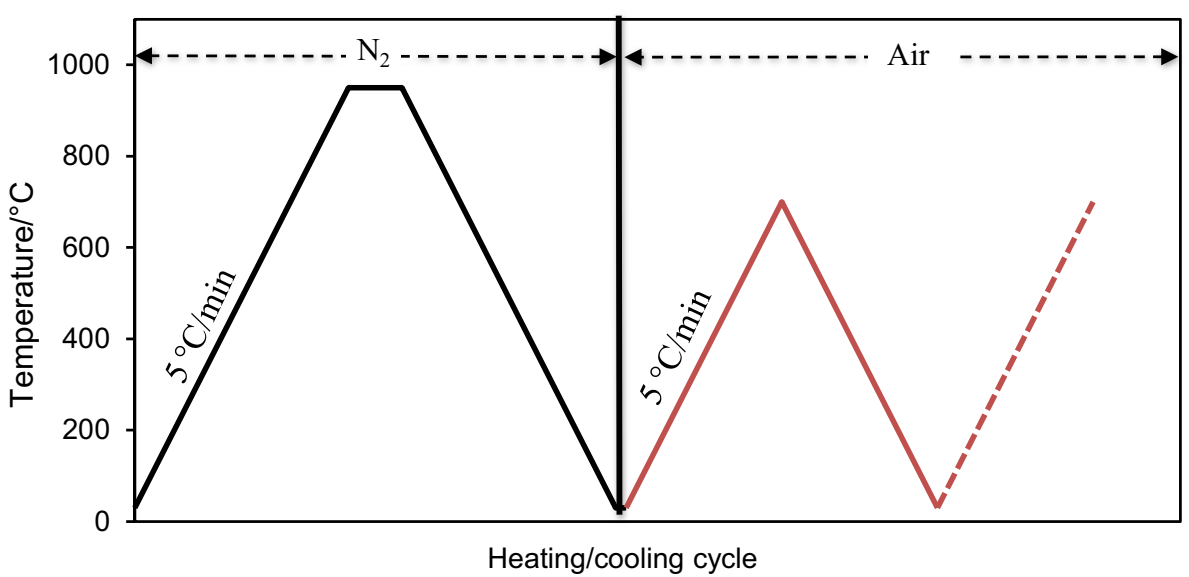

Table 1 Elemental composition of the clay with the concentrations of silicon, aluminum, calcium, iron, potassium and magnesium oxides

\begin{tabular}{lllllll}
\hline Sample & \multicolumn{3}{l}{ Concentration/mass\% } & & \\
\cline { 2 - 6 } & $\mathrm{SiO}_{2}$ & $\mathrm{Al}_{2} \mathrm{O}_{3}$ & $\mathrm{CaO}$ & $\mathrm{Fe}_{2} \mathrm{O}_{3}$ & $\mathrm{~K}_{2} \mathrm{O}$ & $\mathrm{MgO}$ \\
\hline Clay & 57.1 & 14.5 & 8.92 & 6.20 & 3.04 & 2.21 \\
\hline
\end{tabular}

The flexural strength of the SiC/clay ceramic $\left(\sigma_{\mathrm{f}}\right)$ was estimated from Eq. 3, where $F_{\text {Max }}$ is the maximum force, $L$ is the loading span, $\mathrm{B}$ is the breadth, and $\mathrm{H}$ is the height of the flexural samples [24].

The consecutive thermal charge/discharge cycles were simulated using TG-DSC analysis. Figure 1 shows the procedure of this test. The first heating/cooling cycle represents the firing process of the clay ceramic (see "Processing of the clay ceramics" section) under $\mathrm{N}_{2}$ atmosphere to avoid $\mathrm{SiC}$ oxidation. Following this step, the fired clay ceramic was submitted to 20 successive heating/cooling cycles under air atmosphere. For each cycle, the sample was heated from 30 to $700{ }^{\circ} \mathrm{C}$ in order to keep lower than the oxidation temperature with the controlled heating rate of $5^{\circ} \mathrm{C} \mathrm{min}{ }^{-1}$. Then, the furnace was freely cooled down to $30^{\circ} \mathrm{C}$ before moving to the next cycle. This test allowed evaluating the thermal stability of the elaborated ceramic under air atmosphere as heat transfer fluid in a TES system.

\section{Results}

\section{Characterization of the raw materials}

Table 1 shows the elemental composition of the clay, obtained by XRF analysis. The results indicate a predominance of silicon and aluminum oxides. Lower concentrations of calcium, iron, potassium and magnesium oxides can also be observed. The elements from organic substances that cannot be detected by XRF, such as $\mathrm{C}, \mathrm{H}, \mathrm{O}, \mathrm{N}$ or $\mathrm{S}$, account for $8 \mathrm{mass} \%$.
Table 2 Specific surface area and true density of the starting materials used in this work

\begin{tabular}{llll}
\hline Powder & Clay & SiC_LD & SiC_HD \\
\hline True density $/ \mathrm{g} \mathrm{cm}^{-3}$ & 2.69 & 3.16 & 3.42 \\
$S_{\text {BET }} / \mathrm{m}^{2} \mathrm{~g}^{-1}$ & 24 & 29 & $<3$ \\
\hline
\end{tabular}

The specific surface area $\left(S_{\mathrm{BET}}\right)$ and the true density of the raw materials are given in Table 2. It can be observed that $\mathrm{SiC} \_$HD has a lower specific surface area than SiC_LD. However, the results confirm that SiC_HD has a higher density than $\mathrm{SiC} \_$LD.

Figure 2 shows the particle size distribution of the $\mathrm{SiC}$ additives that are used in the study. The results indicate that SiC_HD has a particle size distribution ranging from 10 to $100 \mu \mathrm{m}$ with an average particle size of $30 \mu \mathrm{m}$. On the other hand, $\mathrm{SiC} \_$LD has a wider particle size distribution ranging from $100 \mu \mathrm{m}$ to $1000 \mu \mathrm{m}$. Its average particle size is equivalent to $375 \mu \mathrm{m}$.

Figure 3 shows the TG curves of the raw materials under air atmosphere. For the clay, a number of mass losses are observed when increasing the temperature. These are attributed to the dehydration at temperatures between $30^{\circ} \mathrm{C}$ and $200{ }^{\circ} \mathrm{C}$, dehydroxylation of the clay minerals at temperatures between $400{ }^{\circ} \mathrm{C}$ and $650{ }^{\circ} \mathrm{C}$ and decarbonation of calcium carbonates at temperatures between $650^{\circ} \mathrm{C}$ and $850^{\circ} \mathrm{C}[26$, 35]. It can be observed that the thermal behavior of the $\mathrm{SiC}$ additives is relatively similar. They are both stable at temperatures up to $800{ }^{\circ} \mathrm{C}$ and subjected to oxidation into $\mathrm{SiO}$ and $\mathrm{SiO}_{2}$ at temperatures above $800{ }^{\circ} \mathrm{C}[36,37]$, leading to 


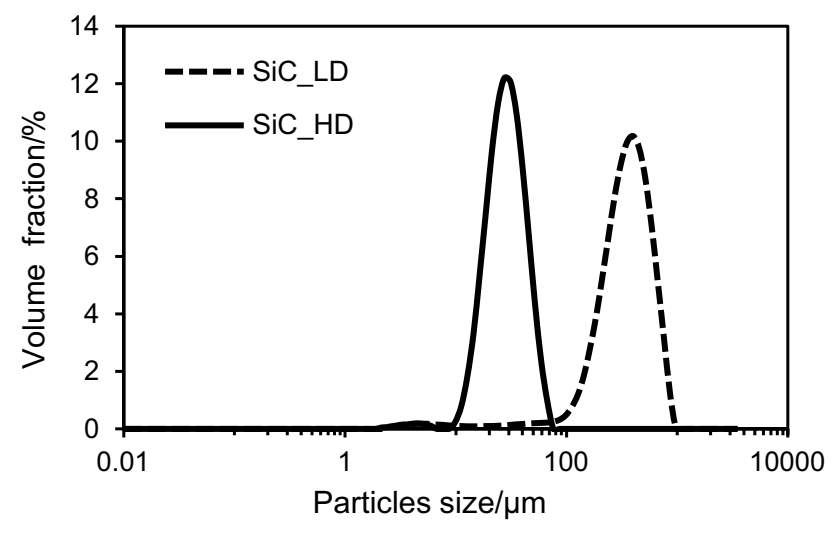

Fig. 2 Particle size distribution of the starting materials used in this work

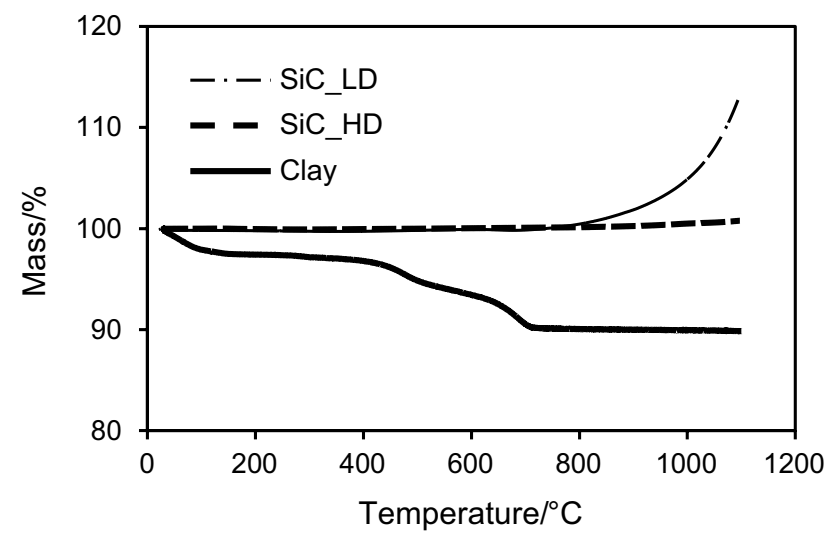

Fig. 3 TG curves of the raw materials under air atmosphere (heating rate of $5{ }^{\circ} \mathrm{C} \mathrm{min}^{-1}$ )

mass increase. It is important to note that the oxidation rate of $\mathrm{SiC} \_\mathrm{HD}$ is very low in comparison with that of $\mathrm{SiC} \_\mathrm{LD}$.

\section{Thermal behavior of the SiC/clay ceramic}

Figure 4 shows the dependence of the percentage of $\mathrm{SiC}$ additives on the firing temperature of the $\mathrm{Si}$ /clay ceramics. In accordance with the thermal behavior of the raw materials, the percentage of $\mathrm{SiC}$ additives is not modified at temperatures up to $800{ }^{\circ} \mathrm{C}$. An increase in the percentage of $\mathrm{SiC}$ additives can be observed at higher temperatures of $800{ }^{\circ} \mathrm{C}$ to $1100^{\circ} \mathrm{C}$. This corresponds to the oxidation of the $\mathrm{SiC}$ additives in the clay ceramic, which is associated with a mass increase. However, the results also show that the increase in the percentage of SiC_HD is much lower than the increase in the percentage of $\mathrm{SiC}_{-} \mathrm{LD}$. This means that the clay ceramics that are doped with $\mathrm{SiC}_{-} \mathrm{HD}$ have a greater thermal stability than the clay ceramics that are doped with SiC_LD. It is important to note that the densification of the

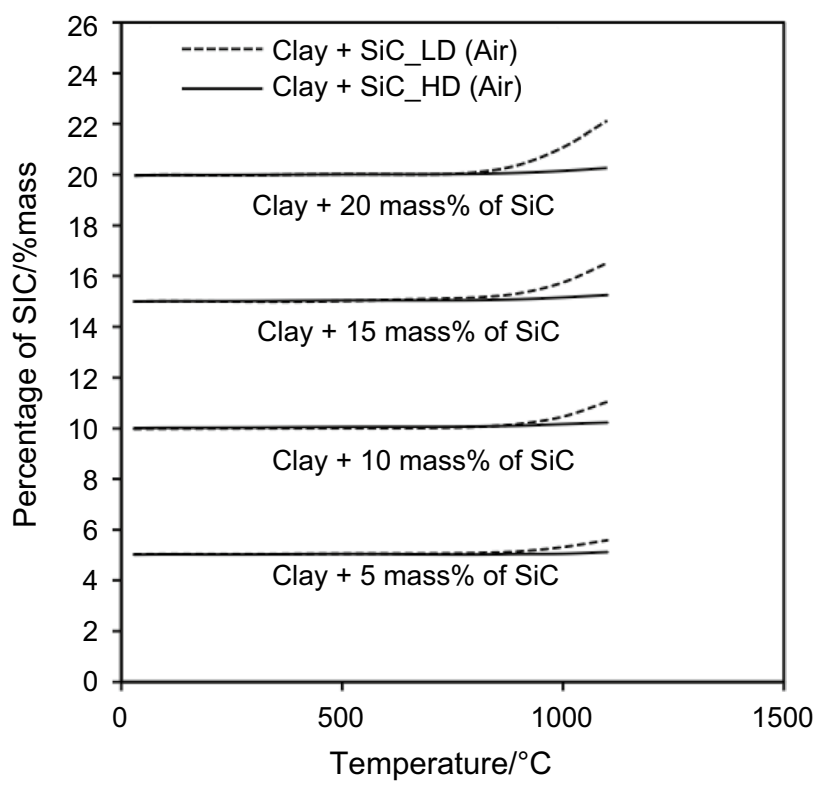

Fig. 4 Dependence of the percentage of $\mathrm{SiC}$ additives on the firing temperature of the clay ceramics doped with 5, 10, 15 and 20 mass\% of $\mathrm{SiC} \_\mathrm{LD}$ and $\mathrm{SiC} \_\mathrm{HD}$ (heating rate of $5{ }^{\circ} \mathrm{C} \mathrm{min}^{-1}$ )

clay matrix starts at a temperature of approximately $850{ }^{\circ} \mathrm{C}$ [38]. This is the reason why it is mandatory to fire the $\mathrm{SiC} /$ clay ceramics at this temperature despite the partial oxidation of $\mathrm{SiC}$ additives.

\section{Bulk density $\left(\rho_{\text {Bulk }}\right)$, percentage of porosity $(\varepsilon)$ and SEM analysis}

Figure 5 shows the bulk density $\left(\rho_{\text {Bulk }}\right.$ ) of the fired $\mathrm{SiC} /$ clay ceramics. The addition of SiC_LD decreases their bulk density, despite the higher density of the SiC_LD additive (i.e., $3.16 \mathrm{~g} . \mathrm{cm}^{3}$ ) than that of the fired clay ceramic (i.e., $1.94 \mathrm{~g} . \mathrm{cm}^{3}$ ). This can be attributed to the large particle size of the SiC_LD additive. In fact, the SEM micrographs in Fig. 6 indicate that the SiC_LD additive conserves its large particle size of approximately $375 \mu \mathrm{m}$ during the firing step. Hence, the large particles of $\mathrm{SiC}_{-} L D$ limit the densification at temperatures above $800{ }^{\circ} \mathrm{C}$. This also corresponds to a significant increase in the volume fraction of pores, as shown in Fig. 7. In contrast, the average particle size of SiC_HD additive is approximately of $30 \mu \mathrm{m}$, which was much smaller than that of $\mathrm{SiC} \_$LD. It also has a higher density (i.e., $3.42 \mathrm{~g} . \mathrm{cm}^{3}$ ) than that of the $\mathrm{SiC} \_$LD additive. Therefore, the ceramic doped with SiC_HD additive has a higher bulk density with a smaller volume fraction of pores than the ceramic doped with $\mathrm{SiC}_{-} \mathrm{LD}$ additive. This was confirmed by the SEM observations (Fig. 6) along with the evolution of the percentage of porosity $(\varepsilon)$ (Fig. 7). SEM analyses of polished ceramics without or with 10 mass\% of $\mathrm{SiC}$ addition show the presence of macro-porosity within the 


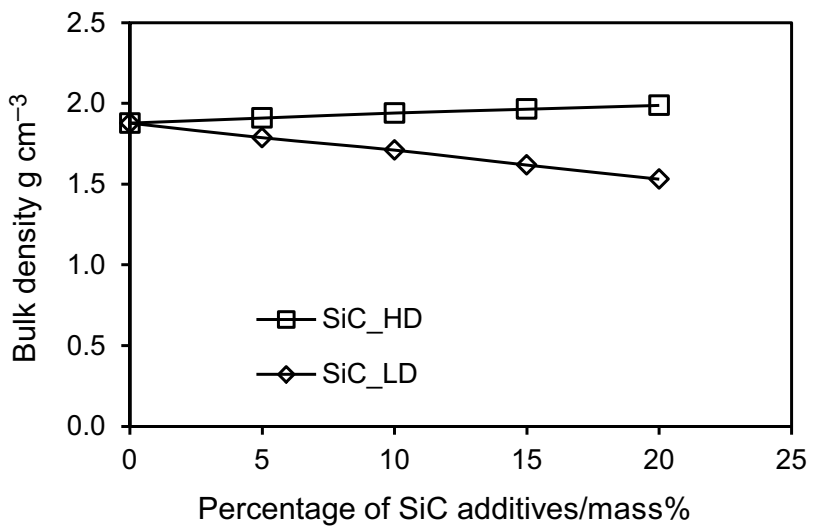

Fig. 5 Bulk density of the ceramics with and without addition of SiC_LD and SiC_HD after firing process at $950{ }^{\circ} \mathrm{C}$ under air atmosphere samples. The analysis of all images of each sample (Fig. 6) showed that macro-porosity was more frequently observed in the sample doped with SiC_LD than that doped with SiC_HD. In Fig. 7, the addition of SiC_LD leads to linearlike increase in the percentage of porosity $(\varepsilon)$. As shown in Figs. 3 and 4, SiC_LD was easier to be oxidized under air atmosphere and it was possible that during the densification at $950{ }^{\circ} \mathrm{C}, \mathrm{SiC} \_\mathrm{LD}$ was partially oxidized to release $\mathrm{CO}$ and $\mathrm{CO}_{2}$ as gas products. Gas emissions conducted to the increase in total porosity of SiC_LD-containing ceramics. On the other hand, SiC_HD was only slightly oxidized up to $950{ }^{\circ} \mathrm{C}$ when it was incorporated in clay matrix (Fig. 4). Gas products must be not notably formed during the densification of clay-SiC_HD mixture. In addition, SiC_HD was non-porous and had higher true density compared to the initial clay. Thus, the addition of SiC_HD decreased the total percentage of porosity of the corresponding ceramics.
Fig. 6 Illustration of SEM images of fired clay ceramics: a $0 \% \mathrm{SiC} ; \mathbf{b}$ clay $+10 \%$ SiC_LD; and $\mathbf{c}$ clay $+10 \%$ SiC_HD
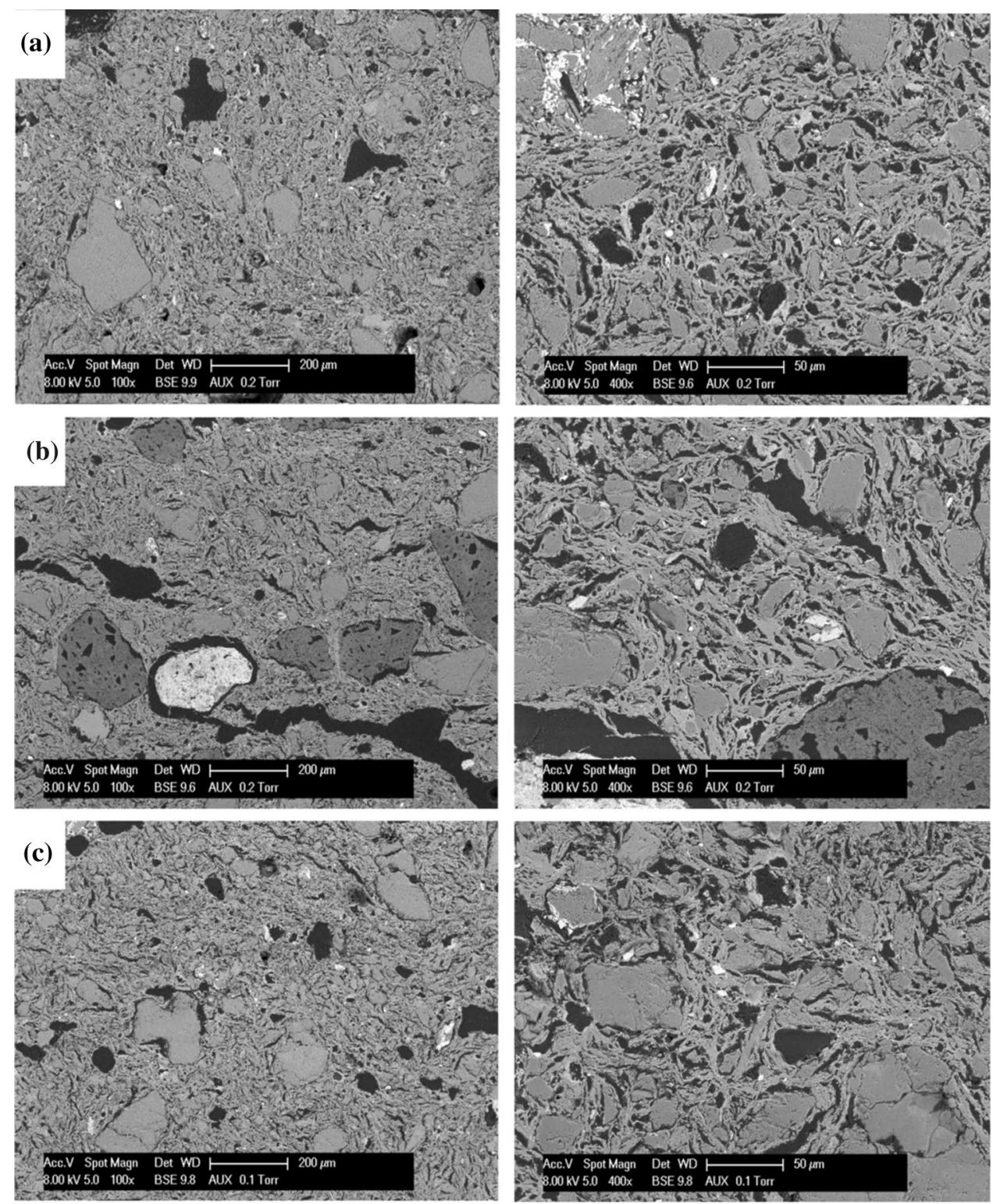


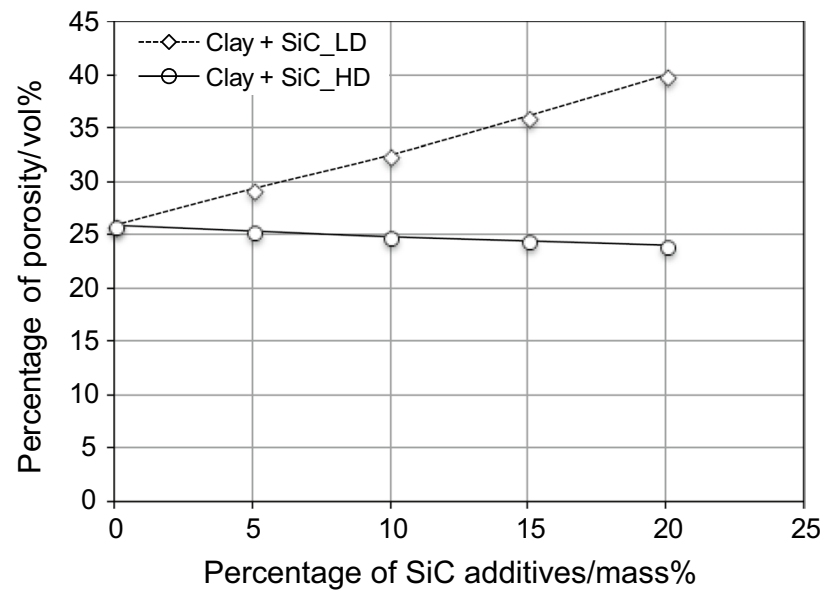

Fig. 7 Evolution of total porosity as a function of $\mathrm{SiC}$ additives contents after firing at $950{ }^{\circ} \mathrm{C}$ under air atmosphere

In summary, SiC_HD had smaller average particle size and was more resistant to air oxidation compared to $\mathrm{SiC}_{-}$ LD. Thus, ceramics prepared with SiC_HD had higher bulk density and lower volume fraction of pores compared to those prepared with $\mathrm{SiC}_{-} \mathrm{LD}$. It is important to note that the bulk density is one of the predominant parameters in the evaluation of a monolithic material for TES application. It is proportional to the energy density stored by the monolithic material. Thus, it is preferable to use $\mathrm{SiC} \_\mathrm{HD}$ for the elaboration of fired clay ceramics as TES materials.

\section{Thermal properties}

Figure 8 shows the evolution of the thermal conductivity of the $\mathrm{SiC}$ /clay ceramics as a function of $\mathrm{SiC}$ content. In general, $\mathrm{SiC}$ is known as a good thermal conductor and its thermal conductivity can vary in a large range [39]. The addition of $\mathrm{SiC}$ into the fired clay matrix was to improve the low thermal conductivity of this material. For our ceramics, the thermal conductivity slightly decreased with SiC_LD addition. This can be explained by the increase in the porosity due to $\mathrm{SiC}$ degradation (Fig. 7). On the other hand, SiC_HD addition allowed increasing the thermal conductivity of the corresponding ceramics. The thermal conductivity of the ceramic containing 20 mass $\%$ of SiC_HD reached $1.00 \mathrm{~W}$ $\mathrm{m}^{-1} \mathrm{~K}^{-1}$ or $33.3 \%$ higher than that of the non-doped ceramic. This matches well with the results of the bulk density and porosity in Figs. 5 and 7. Typically, the SiC_HD additive can be considered as a relevant additive for the improvement of the thermal conductivity of fired clay ceramics.

Figure 9 shows the evolution of the specific heat capacity of the synthesized ceramics. SiC addition did not lead to a notable change in the value of the specific heat capacity of the initial non-doped ceramic, which was stable around $0.65 \mathrm{~kJ} \mathrm{~kg}^{-1} \mathrm{~K}^{-1}$. This value was already found in the

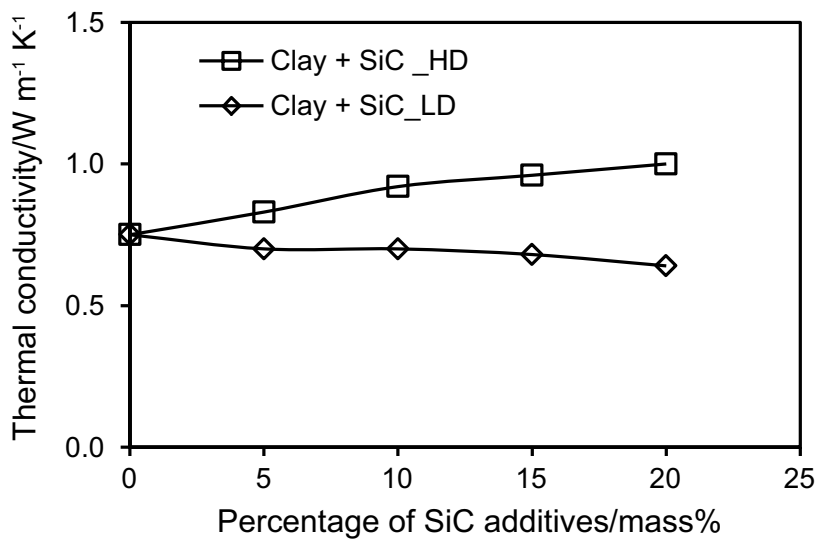

Fig. 8 Thermal conductivity of the fired clay ceramics

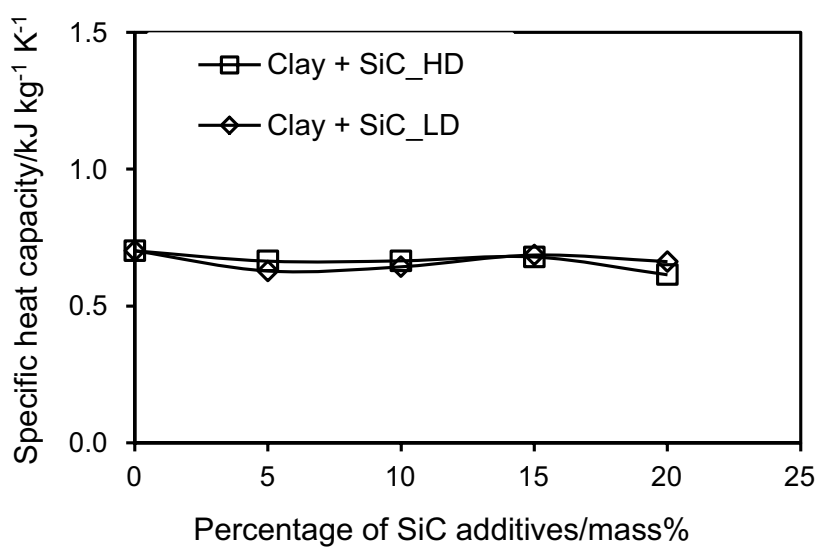

Fig. 9 Specific heat capacity of the fired clay ceramics

previous work using the clay sampled from the same region $[26,38]$. We suppose that $\mathrm{SiC}$ additives used in this work had similar specific heat capacity compared to that of the initial non-doped ceramic. SiC particles embedded in the clay matrix probably did not create new chemical bonds within this matrix. So, the specific heat capacity did not vary with different $\mathrm{SiC}$ contents.

\section{Flexural strength}

The dependence of the flexural strength on the percentage of $\mathrm{SiC}$ additives is presented in Fig. 10. The results show that the non-doped ceramic has a relatively high flexural strength of 13.4 MPa. The addition of SiC_LD results in a significant decrease in the flexural strength. This can be attributed to the large particle size of the SiC_LD additive, along with the increase in the pore volume fraction (see Fig. 7). On the other hand, the addition of SiC_HD to the clay ceramic results in a significant increase in the flexural strength. The flexural strength of the fired clay ceramic increases from 13.4 MPa to 20.0 MPa using a 20 mass\% 


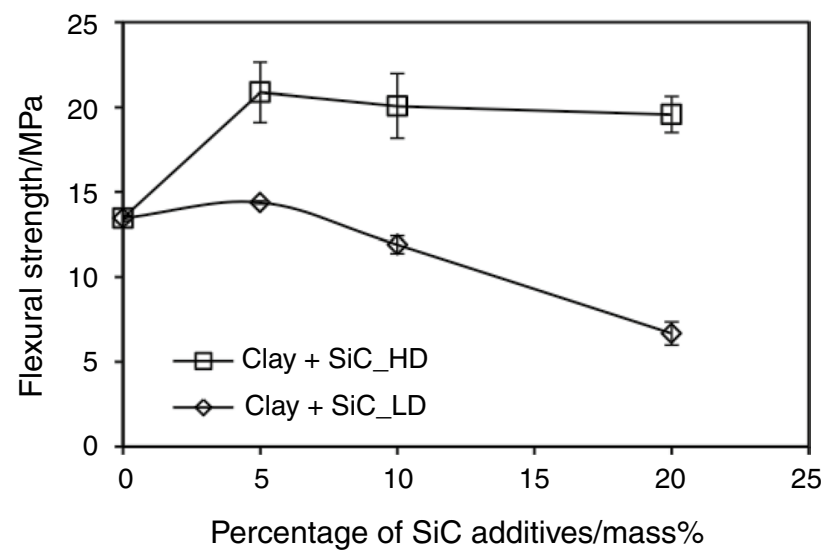

Fig. 10 Dependence of the flexural strength on the percentage of SiC additives after firing at $950{ }^{\circ} \mathrm{C}$ under air atmosphere

addition of SiC_HD. This is due to the fact that SiC_HD contained smaller particles (i.e., $30 \mu \mathrm{m}$ ) than that of $\mathrm{SiC} \_L D$ (i.e., $375 \mu \mathrm{m}$ ). These particles could be easily integrated within the clay matrix, as observed by SEM analysis. This was associated with an increase in the bulk density (Fig. 5) and a decrease in porosity (Fig. 7) that reduced the structural defects of the initial non-doped ceramic. For TES application, ceramics of high mechanical stability are required to build robust monolithic media.

\section{Consecutive thermal charge/discharge cycles}

The results above demonstrated the interest of incorporation of $\mathrm{SiC}_{-} \mathrm{HD}$ into the clay matrix to obtain highly performing ceramics for TES application. SiC_HD addition allowed increasing both the mechanical stability and thermal conductivity, which are two main criteria researched for valorizing clay-based ceramics in TES application. But other parameters are also favored by $\mathrm{SiC}_{-} \mathrm{HD}$ addition including the decrease in porosity and the increase in bulk density, without significant modification of specific heat capacity. The ceramic containing 20 mass\% seemed to be the most interesting by its mechanical, physical and thermal properties. It had the highest thermal conductivity, the highest bulk density, the lowest porosity and the equivalent specific heat capacity and mechanical stability compared to other SiC_HD-containing ceramics. So this ceramic was selected for the simulated thermal charge/discharge cycles in accordance with the test procedure shown by the Fig. 1 .

Figure 11 shows the mass loss of the fired clay ceramic that is doped with 20 mass\% of SiC_HD during 20 heating/ cooling cycles under air atmosphere. For each cycle, the thermal behavior of the ceramic is identical to each other. When the furnace temperature reached $700{ }^{\circ} \mathrm{C}$, the mass loss was recorded at around 0.6 mass \%. But when the furnace was cooled down to $300{ }^{\circ} \mathrm{C}$, the sample mass was restituted to $100 \%$. In reality, this is due to the change of the density of the air with the temperature. In fact, a supplementary TG analysis under the same conditions was conducted with sapphire and the same mass oscillation was observed. After 20 heating/cooling cycles, there was no mass loss and the sample was completely conserved. The results suggest that the fired clay ceramic, doped with 20 mass\% of SiC_HD, is a thermally stable material that is appropriate for a use in TES systems.

\section{Conclusions}

For the first time, the physical, thermal and mechanical properties of $\mathrm{SiC} /$ clay ceramics have been investigated. The properties of the clay-based ceramics were improved by $\mathrm{SiC}$ addition in view of thermal energy storage application. Salient conclusions arising from this study are summarized below:
Fig. 11 Simulated thermal charge/discharge cycles of fired clay ceramic doped with 20 mass\% of SiC_HD under air atmosphere using TG analysis

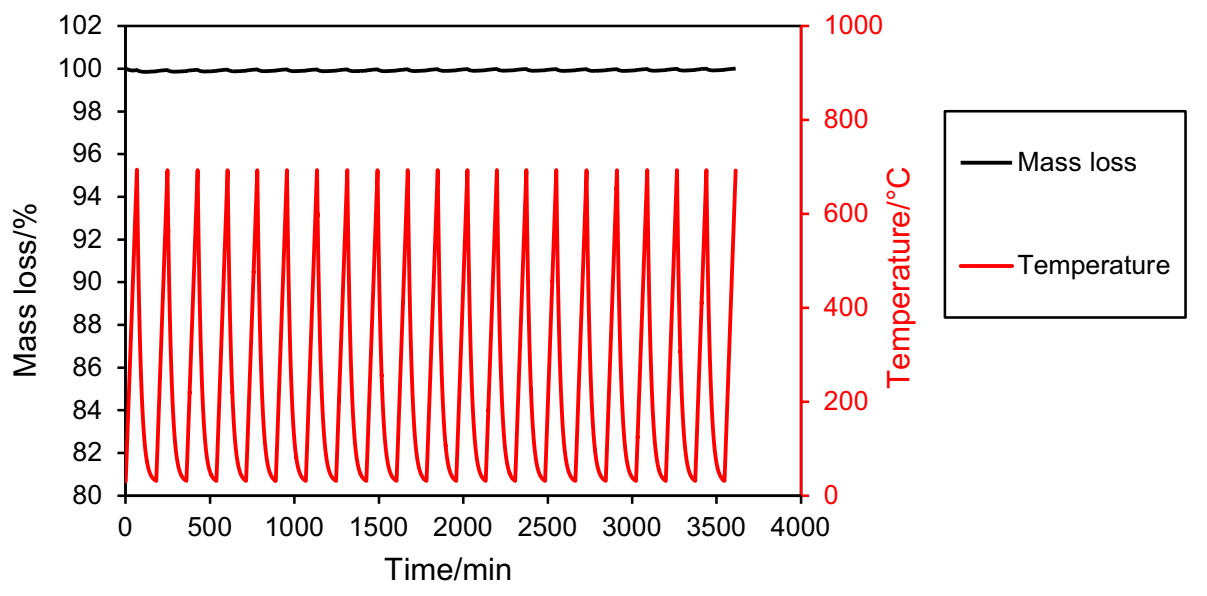


1. The SiC/clay ceramics studied in this work showed a high thermal stability with the temperature. In fact, the $\mathrm{SiC}$ additives remained unchanged in the clay ceramic at temperatures up to $800{ }^{\circ} \mathrm{C}$. The morphology of the $\mathrm{SiC}$ additives was also conserved after firing of the $\mathrm{Si} /$ clay mixtures.

2. The addition of high-density $\mathrm{SiC}$ (SiC_HD) allowed significantly increasing the bulk density and the thermal conductivity (up to $33 \%$ ) of the initial clay ceramic (nondoped ceramic). This could be explained by the intrinsic properties of the high-density $\mathrm{SiC}$ used and the decrease in the volume fraction of pores by $\mathrm{SiC}$ incorporation.

3. The addition of both low-density $\mathrm{SiC}$ and high-density $\mathrm{SiC}$ in the clay ceramic resulted in a similar evolution of the specific heat capacity. In fact, the specific heat capacity of the clay-based ceramics depended on the composition of the additives. The silicon and carbon elements of both $\mathrm{SiC}$ used in this work led to a same improvement of the specific heat capacity.

4. The addition of low-density $\mathrm{SiC}$ decreased the mechanical strength of the clay ceramic due to the increase in the volume fraction of pores in the final ceramics. On the other hand, the high-density $\mathrm{SiC}$ allowed increasing the mechanical strength. Adding a 20 mass $\%$ of high-density $\mathrm{SiC}$ led to $45.5 \%$ of the improvement of the mechanical strength.

The clay/SiC ceramic that contained 20 mass $\%$ of highdensity $\mathrm{SiC}$ had a thermal conductivity of $1 \mathrm{~W} \mathrm{~m}^{-1} \mathrm{~K}^{-1}$, a specific heat capacity of $0.62 \mathrm{~kJ} \mathrm{~kg}^{-1} \mathrm{~K}^{-1}$ and a mechanical strength of 19.6 MPa. The resulting material also showed a high thermal stability after 20 successive heating/cooling cycles. Hence, the current results suggest that clay ceramics with high-density $\mathrm{SiC}$ additives can be a promising material for thermal energy storage application.

\section{References}

1. Cabeza LF, Martorell I, Miro L, Fernández AI, Barreneche C. Introduction to thermal energy storage (TES) systems. In: Cabeza LF, editor. Advances in thermal energy storage systems. Elsevier Ltd: Hoboken; 2015. p. 1-28.

2. Sheikholeslami M. Numerical simulation for solidification in a LHTESS by means of nano-enhanced PCM. J Taiwan Institute Chem Eng. 2018;86:25-41.

3. Sheikholeslami M, Ghasemi A. Solidification heat transfer of nanofluid in existence of thermal radiation by means of FEM. Int J Heat Mass Transf. 2018;123:418-31.

4. Trabelsi SE, Chargui R, Qoaider L, Liqreina A, Guizani A. Techno-economic performance of concentrating solar power plants under the climatic conditions of the southern region of Tunisia. Energy Conv Manag. 2016;119:203-14.

5. Andasol 1: The largest solar power station officially inaugurated. In: DLR, New Archives, Press releases. 2009. https://www.dlr.de/ en/desktopdefault.aspx/tabid-5105/8598_read-17179/8598_page3/. Accessed 17 Mar 2019

6. Dinter F, Gonzalez DM. Operability, reliability and economic benefits of CSP with thermal energy storage: first year of operation of ANDASOL 3. Energy Proc. 2014;49:2472-81.

7. Andasol-2. In: Solarpaces. NREL, Concentrating Solar Power Projects. 2017. https://solarpaces.nrel.gov/andasol-2. Accessed 17 Mar 2019.

8. King of Spain opens Gemasolar plant. Renew Energy. Focus. 2011;12:6.

9. Relloso S, Garcia E. Tower technology cost reduction approach after Gemasolar experience. Energy Proc. 2015;69:1660-6.

10. Solana Generating Station. In: Solarpaces. NREL, Concentrating Solar Power Projects. 2015. https://solarpaces.nrel.gov/ solana-generating-station. Accessed 21 Mar 2019.

11. Noor Ouarzazate. In Masen. 2015. http://www.masen.ma/fr/ publications/rapports/noor-ouarzazate. Accessed 21 Mar 2019.

12. Fernández AG, Galleguillos H, Fuentealba E, Pérez FJ. Thermal characterization of HITEC molten salt for energy storage in solar linear concentrated technology. J Thermal Anal Calor. 2015;122(1):3-9.

13. Ushak S, Fernández AG, Grageda M. Using molten salts and other liquid sensible storage media in thermal energy storage (TES) systems. In: Cabeza LF, editor. Advances in thermal energy storage systems. Elsevier Ltd: Hoboken; 2015. p. 49-63.

14. Kuravi S, Trahan J, Goswami DY, Rahman MM, Stefanakos EK. Thermal energy storage technologies and systems for concentrating solar power plants. Prog Energy Combust Sci. 2013;39:285-319.

15. Faik A, Guillot S, Lambert J, Veron E, Ory S, Bessada C, Echegut $\mathrm{P}, \mathrm{Py} \mathrm{X}$. Thermal storage material from inertized wastes: evolution of structural and radiative properties with temperature. Sol Energy. 2012;86:139-46.

16. Technology roadmap: Solar photovoltaic energy. In: International Energy Agency publications; 2014. https://www.iea.org/ publications/freepublications/publication/TechnologyRoadm apSolarPhotovoltaicEnergy_2014edition.pdf. Accessed 17 Mar 2019.

17. Peiro G, Gasia J, Miro L, Prieto C, Cabeza LF. Experimental analysis of charging and discharging processes, with parallel and counter flow arrangements, in a molten salts high temperature pilot plant scale setup. Appl Ener. 2016;178:394-403.

18. Gil A, Medrano M, Martorell I, Lazaro A, Dolado P, Zalba B, Cabeza LF. State of the art on high temperature thermal energy storage for power generation. Part 1-Concepts, materials and modellization. Renew Sustain Energy Rev. 2010;14:31-55.

19. Meffre A. Matériaux de stockage thermique haute température issus de la valorisation de matières premières secondaires inorganiques. Ph.D. thesis. Université de Perpignan Via Domitia; 2012.

20. Gutierrez A, Miro L, Gil A, Aseguinolaza JR, Barreneche C, Calvet N, Py X, Fernandez AI, Grageda M, Ushak S, Cabeza LF. Advances in the valorization of waste and by-product materials as thermal energy storage (TES) materials. Renew Sustain Energy Rev. 2016;59:763-83.

21. Ortega-Fernandez I, Calvet N, Gil A, Rodriguez-Aseguinolaza J, Faik A, Aguanno BD. Thermophysical characterization of a by-product from the steel industry to be used as a sustainable and low-cost thermal energy storage material. Energy. 2015;89:601-9.

22. Motte F, Falcoz Q, Veron E, Py X. Compatibility tests between Solar Salt and thermal storage ceramics from inorganic industrial wastes. Appl Energy. 2015;155:14-22.

23. Laing D, Lehmann D, Fiss M, Bahl C. Test results of concrete thermal energy storage for parabolic trough power plants. J Sol Energy Eng. 2009. https://doi.org/10.1115/1.3197844.

24. ASTM D790-17. Standard Test Methods for Flexural Properties of Unreinforced and Reinforced Plastics and Electrical Insulating 
Materials. In: ASTM International. West Conshohocken. 2017. www.astm.org. Accessed 17 March 2019.

25. Siegel N, Gross M, Ho C, Phan T, Yuan J. Physical properties of solid particle thermal energy storage media for concentrating solar power applications. Energy Proc. 2014;49:1015-23.

26. Nigay PM. Etude des transformations microstructurales de mélanges argile biomasse lors de la cuisson et relations avec les propriétés mécaniques et thermiques. Ph.D. thesis. Université de Toulouse; 2015.

27. Cobîrzan N, Thalmaier G, Balog AA, Constantinescu H, Timiş I, Streza M. Thermophysical properties of fired clay bricks with waste ceramics and paper pulp as pore-forming agent. J Therm Anal Calorim. 2018;134(1):843-51.

28. Papadopoulou DN, Lalia-Kantouri M, Stratis JA. Thermal and mineralogical contribution to the ancient ceramics and natural clays characterization. J Therm Anal Calorim. 2006;84(1):39-45.

29. Wijesundara M, Azevedo R. Silicon carbide microsystems for harsh environments. Berlin: Springer; 2011. p. 15-29.

30. Abderrazak H, Hmida ESBH. Silicon carbide: synthesis and properties. In: Gerhardt R, editor. Properties and applications of silicon carbide. Rijeka: In Tech; 2011. p. 351-88.

31. Kaur S, Riedel R, Ionescu E. Pressureless fabrication of dense monolithic SiC ceramics from a polycarbosilane. J Eur Ceram Soc. 2014;34:3571-8.

32. Slack GA. Thermal conductivity of pure and impure silicon, silicon carbide, and diamond. J Appl Phys. 1964;35:3560-6.

33. Burgemeister EA, von Muench W, Pettenpaul E. Thermal conductivity and electrical properties of $6 \mathrm{H}$ silicon carbide. J Appl Phys. 1979;50:5790-4.
34. Román-Manso B, Chevillotte Y, Osendi MI, Belmonte M, Miranzo P. Thermal conductivity of silicon carbide composites with highly oriented graphene nanoplatelets. J Eur Ceram Soc. 2016;36:3987-93.

35. Earnest CM. Thermal analysis of selected illite and smectite clay minerals. Part I. Illite clay specimens. In: Smykatz-Kloss W, Warne SSJ, editors. Thermal analysis in the geosciences. Berlin: Springer; 1991. p. 270-90.

36. Silvestroni L, Landi E, Bejtka K, Chiodoni A, Sciti D. Oxidation behavior and kinetics of $\mathrm{ZrB}_{2}$ containing $\mathrm{SiC}$ chopped fibers. $\mathrm{J}$ Eur Ceram Soc. 2015;35:4377-87.

37. Zhu J, Shi P, Wang F, Zhao T. Preparation of the moon-white glaze by carbothermic reduction of $\mathrm{Fe}_{2} \mathrm{O}_{3}$ and $\mathrm{SiC}$. J Eur Ceram Soc. 2015;35:4603-9.

38. Nigay PM, Cutard T, Nzihou A. The impact of heat treatment on the microstructure of a clay ceramic and its thermal and mechanical properties. Ceram Int. 2017;43:1747-54.

39. Malakkal L, Szpunar B, Siripurapu RK, Szpunar JA. Thermal conductivity of bulk and nanowire of cubic-SiC from ab initio calculations. Comput Mater Sci. 2017;128:249-56.

Publisher's Note Springer Nature remains neutral with regard to jurisdictional claims in published maps and institutional affiliations. 